\title{
BED BATHS: NURSING STAFF WORKLOAD AND PATIENT SAFETY ${ }^{1}$
}

\author{
Gisele Möller², Ana Maria Müller de Magalhães ${ }^{3}$
}

\begin{abstract}
1 Paper based on the Course Conclusion Monograph - Care with the bed bath: implications for the nursing team workload, presented to the Escola de Enfermagem at Universidade Federal do Rio Grande do Sul (UFRGS) in 2014. Research with funding PROPESQ/UFRGS - Scientific Initiation Grant and Research Incentive Fund of Hospital de Clínicas de Porto Alegre (HCPA).

${ }^{2}$ Nurse at Hospital Ernesto Dornelles. Porto Alegre, Rio Grande do Sul, Brazil. E-mail: moller.gisele@gmail.com

${ }^{3}$ Ph.D. in Nursing. Faculty, Escola de Enfermagem and Programa de Pós-Graduação em Enfermagem, UFRGS. Nursing Coordinator of HCPA. Porto Alegre, Rio Grande do Sul, Brazil. E-mail: amagalhaes@hcpa.ufrgs.br
\end{abstract}

\begin{abstract}
The goal in this study was to examine the characteristics of the nursing staff's work organization with regard to bed baths. This observational study was conducted with a mixed methods approach and concurrent data collection at inpatient units of a university hospital. The population consisted of adult inpatients and nursing professionals. The sample consisted of 67 patients and 62 professionals. After thematic data analysis, the following established category was found: Potential Risks to the Safety of Professionals and Patients, along with four other emerging categories: Comprehensive Care, Facilities, Organization of Care Processes, and Patient Satisfaction. The descriptive statistical analysis of the quantitative data showed that bed baths lasted an average $15.02 \mathrm{minutes}$. In $55.2 \%$ of the bed baths observed, two professionals were involved. The size of the nursing staff and the inappropriate workspaces affect the organization of care and can lead to adverse events for professionals and patients.
\end{abstract}

DESCRIPTORS: Baths. Skin care. Workload. Nursing care. Patient safety.

\section{BANHO NO LEITO: CARGA DE TRABALHO DA EQUIPE DE ENFERMAGEM E SEGURANÇA DO PACIENTE}

RESUMO: O objetivo do estudo foi levantar características da organização do trabalho da enfermagem relacionado ao banho no leito. Estudo observacional com método misto e coleta de dados concomitante, realizado em unidades de internação de um hospital universitário. A população foi composta por pacientes adultos internados e profissionais de enfermagem. A amostra foi de 67 pacientes e 62 profissionais. Após análise temática dos dados, encontrou-se uma categoria prévia: Riscos potenciais à segurança dos profissionais e pacientes; e outras quatro categorias emergentes: integralidade do cuidado, estrutura física, organização do processo de cuidado e satisfação do paciente. Nos dados quantitativos, após análise por estatística descritiva, encontrou-se um tempo médio de duração do banho no leito de 15,02 minutos. Em 55,2\% dos banhos de leito observados, estavam envolvidos dois profissionais. O dimensionamento do pessoal de enfermagem e os ambientes de trabalho inadequados influenciam na organização do cuidado e podem ocasionar eventos adversos para os profissionais e pacientes.

DESCRITORES: Banhos. Higiene da pele. Carga de trabalho. Cuidados de enfermagem. Segurança do paciente.

\section{BAÑO EN EL CAMA: CARGA DE TRABAJO DEL EQUIPO DE ENFERMERÍA Y SEGURIDAD DEL PACIENTE}

\begin{abstract}
RESUMEN: El objetivo de este estudio fue levantar características de la organización del trabajo del equipo de enfermería relacionado al baño en el cama. Estudio observacional con método mixto y recolección de datos concomitante, realizado en unidades de internación de un hospital universitario. La población estuvo constituida por pacientes adultos y profesionales de enfermería. La muestra consistió en 67 pacientes y 62 profesionales. Después del análisis temático de los datos se encontró una categoría previa: Riesgos potenciales a la seguridad de los profesionales y pacientes y otras cuatro categorías emergentes: Integralidad del cuidado, Estructura física, Organización del proceso de cuidado y Satisfacción del paciente. En los datos cuantitativos, tras el análisis de la estadística descriptiva, se encontró un tiempo promedio de duración del baño en el cama de 15,02 minutos. En el 55,2\% de los baños en el cama observados estaban involucrados dos profesionales. El dimensionamiento del personal de enfermería y los ambientes de trabajo inadecuados influencian la organización del cuidado y pueden ocasionar eventos adversos para los profesionales y pacientes.
\end{abstract}

DESCRIPTORES: Baños. Higiene de la piel. Carga de trabajo. Cuidados de enfermería. Seguridad del paciente. 


\section{INTRODUCTION}

Nowadays, many Brazilian hospitals are in an alarming situation with regard to the lack of physical and technological structure and an inappropriate contingent of professionals. These situations often remit to health risks for patients and workers in the area.

Studies appoint health problems for nursing professionals due to the environments and unfavorable work situations. ${ }^{1-2}$ In addition, some studies have recently related the occurrence of adverse events with the nursing teams' workload..$^{3-4}$ In that context, in recent studies, nursing has appointed the body hygiene/bed bath as a potential factor for the nursing workload and a relevant factor in terms of the attended patients' level of dependence..$^{5-7}$

In addition, according to some literature findings, the procedures involve risks for the professional's health, as its accomplishment demands intense physical effort from the nursing technicians and auxiliaries, who normally execute this activity. ${ }^{5,8}$ However, it is highlighted that the bed bath should also be done and supervised by nurses, as a fundamental element to assess the patients' skin conditions.

Some studies have also found safety risks for the patients during the bed bath, such as the risk of falls, variation in the clinical condition and accidental extubation in the ICU context. ${ }^{5,9-10}$ In view of these studies that appoint body hygiene/bed bath as a determinant factor in the work load, but that do not go deeper into questions about how this work process takes place, besides the lack of studies on the theme, the objective in this study is to investigate the characteristics of the work organization of the nursing team related to care during the bed bath. The goal is to understand how this care is characterized and to deepen the knowledge on why it is considered a relevant factor in discussions on the workload.

\section{METHOD}

This study uses a mixed-methods approach combining qualitative and quantitative research with a concurrent design. In this type of study, the researcher collects the quantitative and qualitative data simultaneously and elects a main method and a secondary database. ${ }^{11}$ The main method in this study is the qualitative; the quantitative data constituted a secondary database. The combina- tion of the two types of data collection permitted integrating the information.

The study was developed at the Hospital de Clínicas de Porto Alegre (HCPA), at six clinical and surgical wards. Updated ethical approval was sought from the institution's Ethics Committee, as it was part of a project previously approved, entitled "Work load and patient safety: social commitment of nursing leaderships", under number 12-0332. This study covers part of the objectives of that larger study, in terms of surveying characteristics of the work process related to medication care, bed bath and transportation, appointed as some of the main factors of the workload and risks for the patients. An Informed Consent Form was applied to the patients and professionals who were observed during the bed bath. In both cases, the aspects required by CONEP Resolution 466/12 were complied with and the exclusive use of the data for research purposes was guaranteed. ${ }^{12}$

The study population consisted of all adult patients hospitalized at the clinical and surgical wards and all technicians and auxiliaries who were working at the hospital during the data collection period.

The sample size was calculated with a $10 \%$ error margin, $95 \%$ confidence level, in a population of 360 patients hospitalized per month at these units. It was estimated that $30 \%$ of the patients needed a bed bath. The sample consisted of 67 patients, randomly selected among the patients hospitalized between January and March 2014 and who needed bed bath care, besides 62 professionals who performed this care procedure during the work shift observed. It is highlighted that some professionals were observed more than once. The sample included patients over 18 years of age, male and female, who received a bed bath during the shift observed. Patients with problems during the shift observed and who were absent from the ward for tests or procedures were excluded.

The data were collected through direct nonparticipant observation, guided by a structured tool. ${ }^{13}$ In the qualitative part, the bed bath and the pre and post-organization were described in detail. In addition, the professionals were asked how many bed baths they had given during their work shift. The qualitative data were organized in the software NVivo 10 and analyzed using the content analysis technique. ${ }^{14}$

In the quantitative part, information as collected on the length of the bed bath, the number 
of professionals involved and the presence or not of family helpers or caregivers. These data were analyzed using descriptive statistics, ${ }^{13}$ in the software Statistical Package for Social Sciences (SPSS), version 18 for Windows ${ }^{\circledR}$.

\section{RESULTS AND DISCUSSION}

The qualitative information was grouped in thematic categories that describe the complexity of the care with the bed bath and the associated risks, as well as aspects that interfere in the organization of the nursing team's work. Five thematic categories were found. One of them was considered as

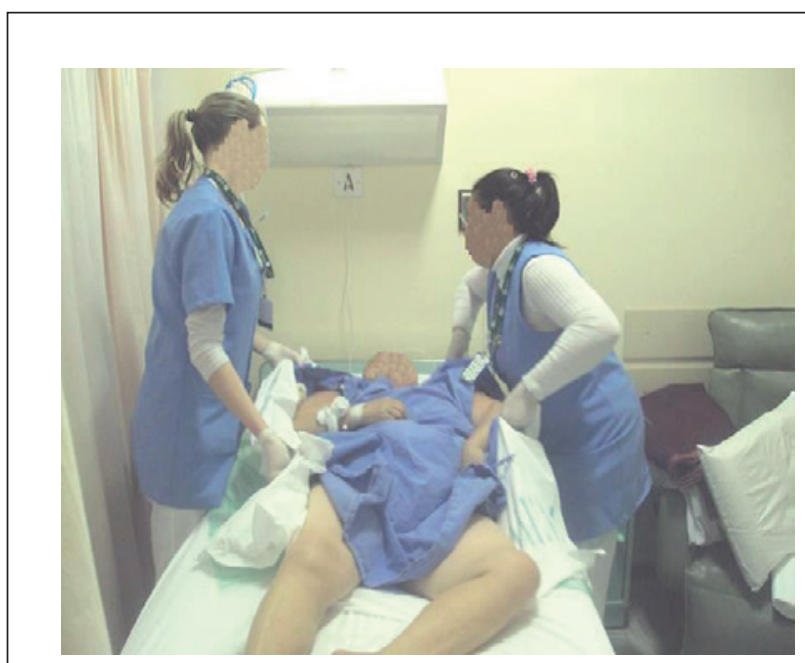

a previously established category: Potential risks to the safety of professionals and patients; and the other four categories were considered as emerging: integrality of patient care, physical structure, organization of the care process and patient satisfaction.

In the previous established category risks to the safety of professionals and patients, "nodes" emerged - registry units and themes - related to the physical effort of the nursing team; risks of patient falls; risks for dislocation of devices; and infection risks.

During the observations, the physical burden of the bed bath procedure was evidenced.

Technician, unable to appropriately lateralize the patient and then pushes him, but unsuccessfully. The technician on the other side pulls with both hands and manages (heavy patient, visible physical effort of technicians). (observation 21);

The worst of the bath is the bed linen! We get all bent... You need to lift the mattress with the patient's weight on top (observation 33)

Figure 1 - Patient mobilization during bed bath, Porto Alegre, 2014

The work by two technicians does not fully exempt the professionals from physical effort; nevertheless, it showed to be safer for the patient and for the professionals involved. The technicians performed the procedure by dividing the patient's body weight and the activities, and planned moves were possible.

When a single nursing professional performed the bath, the work became visibly more exhausting. On those occasions, potential risks were observed for the patient and for the professionals. For the patients, greater exposure was observed to the risk of falls, inappropriate moves, risk for dislocation of devices, besides impaired body hygiene. As regards the professionals, greater physical efforts were made during the procedure, which can cause musculoskeletal damage/injuries.

Most bed baths observed were done by two professionals, 37 (55.2\%), evidencing that doing the procedure in pairs was preferred, probably due to the advantages mentioned earlier. However, in a considerable number of observations, 25 (37.3\%), the professionals were giving the bed bath alone. In some more complex situations, five (7.5\%), up to three nursing technicians had to be involved.

The family member's help during the bed baths happened in only $15(22.4 \%)$ out of 67 observations. This demonstrates that the family member's help is not the strategy the technician prefers, but is mainly adopted in situations when the help of a colleague is not available at the time of the bed bath. This preference may be due to the technical inability of a relative when compared to a nursing professional. It may also be possible that the professionals do not want the relative's presence so that they are not observed during the activity and for the sake of control over the work process. 
The bed bath involves intense physical effort to move the patient and change the bed linen, mainly causing complaints of fatigue and musculoskeletal injuries, which can entail absences from work. ${ }^{5}$ Another study also related the occurrence of Work-Related Musculoskeletal Disorders (WMSD) with the rates of absenteeism, due to the burdening characteristics of the nursing technicians' activities and the inappropriate conditions of their work environments. ${ }^{15}$

Hence, in the management of a ward, the patient acuity should be considered, as well as the mean number of patients who need bed bath care, with a view to appropriately dimensioning the number of professionals needed, minimizing possible sick leaves related to job activities that require greater physical effort.

With regard to patient safety, it was found that the bed bath can be a crucial moment. The risk of falls was observed on some occasions during the bed baths, which coincides with the findings from another study. ${ }^{5}$ Unsafe situations were observed when the patient was left alone for the professional to get some material that was lacking, when (s)he forgot to raise the bed bars at the end of the bath, when the bed was not blocked during the procedure and when moves were made that required too much strength from the technician, causing inappropriate moves in the bed. These considerations remit to the need for further studies on the bed bath and the risks for patient safety.

Another risk observed refers to the dislocation of devices during the bed bath, due to the characteristics of the procedure, which involves moving the patient in the bed and maneuvers to change linen and diapers. Moving the patient can accidentally dislocate tubes, drains, catheters or venous accesses, causing adverse events. When lateralizing the patient, the extender of the central catheter got stock in the bed rail (observation 45).

As to the dislocation of devices during the bed bath, only one reference was found in the literature, in the intensive therapy context, in which the risk of accidental extubation was identified during the bed bath, when changing position, transporting the patient and changing the fixation of the ventilation device. ${ }^{10}$

During the bed bath, the patient is susceptible to infections, as his body is exposed and manipulated by the professionals' hand, which can act as contamination vehicles. In addition, the professionals performing the procedure are vulnerable to infections during the activity, as this is a moment of contact with the patient's body and with possible fluids and secretions. Therefore, it is important for the professionals to use individual protection equipment (IPE) and accomplish the appropriate asepsis technique.

Although the nursing professionals have full individual protection equipment (gloves, gowns etc.) at their disposal, posters are displayed, protocols are available with orientations on the procedure, in different circumstances the infection prevention standards were not complied with, such as: not washing hands; not using protection barriers for patients with multi-resistant germs; use of the same glove for washing and further wound dressing; not changing compresses to wash different body segments (in some situations due to the lack of material); exposure to airway secretions without using appropriate IPE, such as a mask or individual protection glasses.

Hand washing is the simplest and cheapest individual measure to prevent the dissemination of healthcare-associated infections (HAI), which are public problems that cause high spending for the health services. ${ }^{16}$ Hence, it is noteworthy that most professionals did not wash their hands according to the recommendations, as shown in Table 1:

Table 1 - Moments of hand washing by nursing technicians/auxiliary nurses for the bed bath. Porto Alegre-RS, 2014

\begin{tabular}{lrr}
\hline Moments of hand washing & $\mathbf{n}$ & \% \\
\hline Before and after the procedure & 1 & 1.5 \\
Only after the procedure & 24 & 35.8 \\
Only before the procedure & 2 & 2.9 \\
No hand washing & 40 & 59.7 \\
\hline Total & 67 & 100 \\
\hline
\end{tabular}

Among the barriers that influence the nursing team's lack of compliance with standard precautions, the following can be mentioned: emergency situations, availability of equipment, limited professional competence or discomfort due to use, patients' discomfort due to the protection measures, work overload, lack of staff and length of professional experience. ${ }^{17}$

In the category comprehensive care, the nodes related to the patient profile in terms of 
care complexity were grouped, taking into account the patient's emotional conditions and autonomy, the presence of dressings and the clinical/surgical conditions of the patients who received the bed bath. Besides the technique and routine needed to accomplish the procedure, the nursing technicians had to take into account singular and specific issues of each patient, which can interfere in the care.

As regards emotional and motivation issue, it was observed that, when the patient participated in the bed bath, greater interaction took place between the technician and the patient. This contributed positively to the accomplishment of the procedure, even saving the nursing technicians' physical effort in some situations. When possible, the professionals stimulated self-care, rescuing the individual's autonomy and enabling patients to gradually become less dependent on nursing care. On the opposite, when the patients were more dependent or discouraged, the nursing technicians/auxiliary nurses' work was more mechanical.

The presence of dressings was a relative factor, as they were generally performed during the bed bath, with a view to optimizing the nursing tasks. Nevertheless, it was observed that the nursing technician had to get organized "twice", in view of the need to organize other specific material for the dressing (gauze, compresses, saline solution etc.) and, sometimes, the nursing or medical prescription for the dressing had to be verified. This all adds up to the organization and technique for the bed bath itself, which can influence the time spent on patient care.

In a study in which the time spent to apply a dressing was investigated according to the patients' level of dependence, mean times were found that ranged between seven and eight minutes. ${ }^{18}$ Hence, this time adds up to the time for the bed bath when the patient has a dressing, without counting the time to get organized for the procedure.

In the observations, it was also verified that the patient acuity can interfere in the bed bath. Situations in which the patient is considered "heavy" and demands physical effort from the team, when the awareness level is reduced and when the patient cannot help with the movements or does not understand orientations, and even the presence of catheters, drains, venous accesses, orthopedic restrictions or skeletal trac- tion demand greater care when moving in the bed during the bath. Patient with open abdomen with drain in aspiration, urostomy, nasogastric probe (NGP), indwelling urinary probe (IUP), double-lumen catheter, parenteral nutrition (PTN) and lipids, three infusion pumps on one support (observation 55).

In the category physical structure, this theme came up several times in the nursing technicians/ auxiliary nurses report and showed to be a critical point in the understanding about the nursing team's work conditions and, consequently, about their possible relation with the workload. Issues related to the size of the physical space, availability of bathrooms in the rooms and the lack of material to give the bed bath tended to negatively influence the work routine observed. The technician explains that that is why she is always the first to arrange the cart, because afterwards there is always material lacking [...]. She reports that, when there is none she doesn't keep on waiting for it to arrive, in these circumstances she improvises using sterile compresses for example (observation 5).

When the procedure was done in nursing wards, the professionals had to go into the bathroom more to get and change the bath water. The space between the beds, divided by curtains, sometimes became insufficient for the laundry basket, the bathing cart and the other equipment of the patient unit. In addition, during the data collection, in the summer, the environment became extremely warm/humid, mainly with the curtains closed, making the procedure more exhausting. These aspects were discussed in the study, which showed that $53.9 \%$ of the physical risks at the hospital are due to the bad distribution of the physical space. ${ }^{19}$ Hence, the inappropriateness of the physical area and the lack of material can compromise the body care.

The category organization of the work process includes a set of activities that are linked to the professionals' work process and to the bed bath. The nodes in this category area: simultaneous activities and unpredicted situations; patient assessments; baths and changes/scales; need for help and privacy. In that sense, it is relevant to analyze how long the professional is involved in the bed bath, to be able to assess how this care can influence the other nursing activities. 
Table 2 - Time spent (in minutes) by nursing professionals to organize and give the bed bath. Porto Alegre-RS, 2014

\begin{tabular}{lcrrcc}
\hline Time (minutes) & Pre Organization & Bed bath & Post organization & Total organization & Total time \\
\hline No. of observations & 56 & 67 & 61 & 53 & 53 \\
Losses & 11 & - & 6 & 14 & 14 \\
Mean & 06.07 & 15.02 & 05.06 & 12.00 & 26.06 \\
Standard deviation & 02.07 & 05.03 & 03.08 & 04.05 & 06.08 \\
Minimum & 01.09 & 06.09 & 01.09 & 05.09 & 15.00 \\
Maximum & 11.09 & 32.00 & 19.00 & 25.00 & 43.09 \\
\hline
\end{tabular}

As evidenced in the data, the total number of observations for the pre and post-bed bath organization periods differ from the total number of cases observed. The loss of some data was due to the organization process of the units, in which the preparation of the material often happened isolated from the procedure, hampering the data collection. Sometimes, at the end of the bed bath, the material was not organized, due to the team's urgent need to perform other tasks, such as medication administration, transportation or other hygiene care (Table 2).

Based on the data, the relevance of the bed bath in the workday of the nursing team is evidenced. The mean length of 26.06 minutes is considerable for a work shift with that many other activities to be done. In addition, it is not rare for a technician to give more than one bed bath during the shift. Hence, when multiplying this time by the number of baths during the shift, it can be inferred how exhausting and impacting this care can be in the workload. These study findings are similar to two other studies that measured the duration of the bed bath and found an average of 20 to 25 minutes and 30.68 minutes, respectively. ${ }^{18,20}$

The professionals who participated in the 67 bed baths observed were asked about how many baths they gave or would still give during the work shift. The answers ranged between one and five bed baths per shift, according to the nursing technicians and auxiliary nurses, representing an average of 1.83 bed baths per shift for each professional. In 30 observations (44.7\%), the technicians answered that they gave only one bed bath, in 25 observations (37.3\%) the technicians answered two bed baths, in six observations $(8.9 \%)$ three, in five observations $(7.4 \%)$ four and in one observation $(1.4 \%)$ the technician answered giving five bed baths during the work shift observed.

At the wards under study, the patient scales are organized by dividing the number of patients by the number of professionals, without considering the level of complexity of the assisted patients. When the patient needs a bed bath, these are divided between the morning and afternoon shifts through a preset division of the wards (even beds: morning; uneven beds: afternoon). In the work scales, during the study period, each nursing technician had five to seven patients under his/ her care during the shift.

During the data collection, it could be observed that, while the technicians prepared the material, or even during the bed bath, other patients, professionals and family members summoned them. In addition, the professionals often had to cope with unforeseen, unexpected situations, so that they had to reorganize, recreating new work plans. As exemplified in the following excerpt: nursing technician had pulse therapy [glucose verification 30/30min], plus the bed bath and further transportation, all tasks during the same period, the transportation had to wait (observation 66).

It is perceived how complex a care routine becomes in which the professional's initial activity plan is not maintained due to interruptions in the work environment. The low level of control on the planning and execution of the nursing activities harms the workers' health. ${ }^{21}$ In one research, in an observation of 10 hours of nursing work, 43 interruptions were verified, appointing that the non-linearity of nursing work, together with the interruptions in the work, constitute situations in which the nursing professionals can lose the cognitive focus on their priorities and this can lead to care errors, besides the increased stacking of incomplete tasks. ${ }^{22}$

What the patient assessment is concerned, it is known that the bed bath is a favorable circumstance for this evaluation, as the patient's body can be assessed in full length. Therefore, the nursing team needs to look attentively to make the best of this moment and perform a detailed physical examination. As regards the professionals' assessment, the following care for the patients' skin had been incorporated into care: hydration, prevention 
and care for pressure ulcers (PU), rashes and even orientations for patients and family members.

On the opposite, it was also observed that the nurses did not use the moment of the bed bath to assess the patients under their care, losing a singular opportunity for this purpose, as follows: nurse enters the room to see a venous access in the patient but, when she sees that he's having the bath, she goes back and leaves without talking or observing anything (observation 14).

In addition, it was observed that, due to the necessary moving in the bed, the procedure can turn into a painful experience for the patient. The patient reports that the time of the bath is when his bedsore hurts most. She says she'll get a medicine against pain (observation 6).

Therefore, a careful assessment by the technicians and nurses is needed before the bed bath, focusing on the patients' conditions and limitations in terms of movements, with a view to making the procedure less painful for these patients and delivering more qualified care. This assessment should include the review of the medical prescription and analgesic possibilities to reduce the patient's discomfort during the bed bath.

Another issue that emerged in the technicians' reports dealt with the relevance of hygiene care beyond the bed bath, such as diaper change and aspersion baths using a hygienic chair, which are considered activities that impact the workload. The technician comments on the baths with help, which also demand a lot of work and time, the patients are highly dependent! (observation 65).

Hence, it can be inferred that care with body hygiene in general is a critical factor in the workload of the nursing team.

Although most baths observed were given by a pair of technicians $(55.2 \%)$, a considerable number of observations was found $(37.3 \%)$, in which the technicians performed the procedure alone. When questioned about this circumstance, they presented issues related to the workload as an obstacle, that is, the difficulty for another colleague to be able to help or the impossibility to await help due to the work demands all of them are submitted to. When asked about help from a colleague, she answers: 'Here it's you and you! I don't even consider help anymore... Everyone's overburdened! (observation 9).

Due to the difficulties to get help, the nursing professionals sought the strategy of demanding help from colleagues only at the most critical times, such as to lateralize the patient in the bed to wash the back region and change the sheets and to position ("lift") the patient in the bed after the end of the bath, making the patient comfortable.

What privacy is concerned, at the wards where this study was undertaken, the infirmaries have three or two beds separated by curtains and there is free circulation of employees from the multidisciplinary team and the canteen and hygiene professionals. The function of the curtains is to preserve the patient's intimacy, avoiding unnecessary exposure. Despite these considerations, it was observed that, sometimes, in the professionals' routine, the privacy was not preserved. There were times when the curtains were not fully closed or situations in which other professionals appeared during the bed bath and opened the curtains.

Another study found similar results regarding the non-preservation of the patients' privacy during body hygiene care. ${ }^{23-24}$ The professional experience and the workload can make up a thin line that can turn the professionals less cautious in care delivery in terms of preserving the patient's privacy during the bed bath.

In the category patient satisfaction, reports of patients were observed that suggest that the bed bath can turn into a relevant item with regard to the patient's satisfaction with nursing care. The feelings the patients express (pleasure, confidence, welcoming) can help them get through a healthdisease process experienced under that circumstance and tighten the bond patient-professional.

This interaction between patient and nursing professional which is established in health care delivery takes form during the "service meetings", which refer to the moments when the client/user interacts with the frontline professionals in the organization. ${ }^{25}$ A study that assessed the users' satisfaction with the "service meetings" while they were hospitalized found that the service meetings with the nursing team exert the strongest influence on the clients' satisfaction with the hospital..$^{25}$ Hence, the relevance of the bed bath for patient satisfaction can be inferred as this is a service meeting when intimate and constant interaction occurs for an average 15 minutes, during the work shift. Patient praises the bath, says that it's the best time of the day (observation 52).

\section{FINAL CONSIDERATIONS}

It was observed that the physical effort is a risk factor for the professionals' safety, due to the exhaustion, and it is intimately related with the 
team's workload. Therefore, an appropriate dimensioning of the nursing staff becomes relevant for the procedure to be accomplished preferably in pairs or by a larger number of professionals, according to the demand of the patient attended, making the bed bath safer.

Besides the relation with the amount of professionals available, the relevance of work environments that promote complex and discontinued organizational processes was also observed, which favor the professionals' stress and lack of concentration and adaptations to the safety standards with a view to facilitating the work. Hence, all of this involves potential risks each day. The risks related to infection, falls from the bed and dislocation of devices during the bed bath were observed and described as the main potential patient safety risks.

The interruptions, simultaneous and unexpected situations, as well as issues related to the physical structure, make the work environments unpleasant, complicating the practice of safe and qualified care by nursing. That often entails damage to the patients' health and favors a mistaken reading by the institutions and the population of the motives why the errors occur. This is partially due to a culture of blaming the professional which exists in our midst, without envisaging the errors within the context that allowed them to exist, and which in most situations involve outdated and exhausting work processes for the professionals.

In view of these considerations, the importance of carefully analyzing the bed bath and of how the nursing team organizes its activities is highlighted, as these can involve safety risks that often go by unnoticed in a more superficial look. Thus, through the results found in this study, it is relevant to undertake further research on the hygiene care nursing performs in order to understand its true care complexities and possible impacts in the team's nursing work, as well as in the patients' safety.

\section{REFERENCES}

1. Ribeiro NF, Fernandes RCP, Solla DJF, Junior ACS, Junior ASS. Prevalência de distúrbios osteomusculares relacionados ao trabalho em profissionais de enfermagem. Rev Bras Epidemiol. 2012; 15(2):429-38.

2. Ribeiro RP, Martins JT, Marziale MHP, Robazzi MLCC. O adoecer pelo trabalho na enfermagem: uma revisão integrativa. Rev Esc Enferm USP. 2012; 46(2):495-504.
3. Magalhães AMM, Dall'agnol CM, Marck PB. Carga de trabalho da equipe de enfermagem e segurança do paciente - estudo com método misto na abordagem ecológica restaurativa. Rev Latino-Am Enfermagem [online]. 2013 Jan-Fev [acesso 2014 Jun 5]; 21(Spe):[09 telas]. Disponível em: http:/ / www.scielo.br/scielo. php?pid=S0104-11692013000700019\&script $=$ sci $_{-}$ arttext\&tlng=pt

4. Duffield C, Diers D, O'Brien-Pallas L, Aisbett C, Roche $\mathrm{M}$, King $\mathrm{M}$, et al. Nursing staffing, nursing workload, the work environment and patient outcomes. Appl Nurs Res. 2011 Nov; 24(4):244-55.

5. Magalhães AMM. Carga de trabalho de enfermagem e segurança de pacientes internados em um hospital universitário [tese]. Porto Alegre (RS): Universidade Federal do Rio Grande do Sul. Escola de Enfermagem; 2012.

6. Sousa RMC, Padilha KG, Nogueira LS, Miyadahira AMK, Oliveira VCR. Carga de trabalho de enfermagem requerida por adultos, idosos e muito idosos em Unidade de Terapia Intensiva. Rev Esc Enferm USP. 2009; 43(esp 2):1284-91.

7. Araújo VB, Perroca MG, Jericó MC. Variabilidade do grau de complexidade assistencial do paciente em relação à equipe de enfermagem. Rev Latino-Am Enfermagem. 2009; 17(1):29-34.

8. Marçal MA, Fantauzzi MO. Avaliação da prevalência de lombalgia em uma equipe de enfermagem e as condições ergonômicas de seu trabalho. In: Anais do Congresso Brasileiro de Fisioterapia do Trabalho, 2009 Ago 26-28; São Paulo, Brasil. São Paulo (SP): Brasil; 2009.

9. Oliveira AP, Lima DVM. Evaluation of bedbath in critically ill patients: impact of water temperature on the pulse oximetry variation. Rev Esc Enferm USP. 2010; 44(4):1034-40.

10. Castellões TMFW, Silva LD. Guia de cuidados de enfermagem na prevenção da extubação acidental. Rev Bras Enferm. 2007 Jan-Fev; 60(1):106-9.

11. Creswell JW. Projeto de pesquisa: métodos qualitativo, quantitativo e misto. Porto Alegre (RS): Artmed, Bookman; 2010.

12. Ministério da Saúde (BR). Conselho Nacional de Saúde, Comissão Nacional de Ética em Pesquisa. Resolução $n 466$ de 12 de dezembro de 2012: diretrizes e normas reguladoras para as pesquisas envolvendo os seres humanos. Brasília (DF): MS; 2012.

13. Polit DF, Beck CT. Fundamentos de Pesquisa em Enfermagem: Avaliação de evidências para a prática da enfermagem. Porto Alegre (RS): Artmed; 2011.

14. Minayo MCS. O desafio do conhecimento: pesquisa qualitativa em saúde. São Paulo (SP): Hucitec; 2010.

15. Sancinetti TR, Gaidzinski RR, Felli VEA, Fugulin FMT, Baptista PCP, Ciampone MHT, et al. Absenteísmo - doença na equipe de enfermagem: relação com a taxa de ocupação. Rev Esc Enferm USP. 2009; 43(esp): 1277-83. 
16. Brasil. Agência Nacional de Vigilância Sanitária. Segurança do paciente em serviços de saúde: higienização das mãos. Brasília (DF): ANVISA; 2009.

17. Efstathiou G, Papastavrou E, Raftopoulos V, Merkouris A. Factors influencing nurses' compliance with Standard Precautions in order to avoid occupational exposure to microorganisms: A focus group study. BMC Nurs. 2011; 10(1):1-12.

18. Nonino EAPM. Avaliação da qualidade dos procedimentos de enfermagem - banho e curativo - segundo o grau de dependência assistencial dos pacientes internados em um Hospital Universitário [tese]. Ribeirão Preto (SP): Escola de Enfermagem de Ribeirão Preto, Universidade de São Paulo; 2006.

19. Mauro MYC, Paz AF, Mauro CCC, Pinheiro MAS, Silva VG. Condições de trabalho da enfermagem nas enfermarias de um hospital universitário. Esc Anna Nery. 2010 Abr-Jun; 14(1):13-8.

20. Lima AFC, Fugulin FMT, Castilho V, Nomura FH, Gaidzinski RR. Contribuição da documentação eletrônica de enfermagem para aferição dos custos dos cuidados de higiene corporal. J Health Inform. 2012 Dez; 4(esp):108-13.
21. Magnago TSBS, Lisboa MTL, Griep RH, Zeitoune RCG, Tavares JP. Condições de trabalho de profissionais da enfermagem: avaliação baseada no modelo demanda-controle. Acta Paul Enferm [online]. 2010 [acesso 2014 maio 29]; 23(6). Disponível em: http://www.redalyc.org/articulo. oa?id=307023868015

22. Potter P, Boxerman S, Wolf L, Marshall J, Grayson D, Sledge J, et al. Mapping the Nursing Process: a new approach for understanding the work of nursing. JONA. 2004 Fev; 34(2):101-09.

23. Soares NV, Dall'agnol CM. Privacidade dos pacientes - uma questão ética para a gerência do cuidado em enfermagem. Acta Paul Enferm. 2011; 24(5):683-8.

24. Pupulin, JSL, Sawada NO. Privacidade física referente à exposição e manipulação corporal: percepção de pacientes hospitalizados. Texto Contexto Enferm. 2010 Jan-Mar; 19(1):36-44.

25. Moura GMSS, Luce FB. Encontros de serviço e satisfação de clientes em hospitais. Rev Bras Enferm [online]. 2004 [acesso 2014 Jun 5]; 57(4). Disponível em: http://www.scielo.br/pdf/reben/v57n4/v57n4a10 